Int. J. Dev. Biol. 52: 109-114 (2008)

doi: $10.1387 / \mathrm{ijdb} .072339 \mathrm{mj}$

\title{
Stanislaw Smreczynski's legacy and the Department of Zoology of the Jagiellonian University of Krakow (Poland)
}

\author{
MARIUSZ K. JAGLARZ* \\ Institute of Zoology, Jagiellonian University, Krakow, Poland
}

\begin{abstract}
This article covers the origin and development of scientific interest in insect and amphibian developmental biology at the Department of Systematic Zoology and Zoogeography of the Jagiellonian University. The greater part of this historical account is devoted to Professor Stanislaw Smreczynski (1899-1975), the founding father of the Department, and comments on his biography and research achievements in the field of animal experimental embryology. A particular emphasis is on Smreczynski's contributions to contemporary understanding of early embryonic development of amphibians and insects as well as his expertise in Pleistocene and extant weevils (Curculionidae). A concise survey of developmental phenomena studied by some of Smreczynski's co-workers and followers is also presented, including the early embryogenesis of entognathans as well as germ cell determination and gonad formation in Drosophila virilis conducted by Jura; analysis of oogenesis in Collembola carried out by Krzysztofowicz; investigations of insects and tradigrades by Weglarska, and finally research into various aspects of ovary structure in diverse insect taxa by the Bilinski group.
\end{abstract}

KEY WORDS: history, developmental biology, insect, amphibian experimental embryology, oogenesis

It is not always easy or possible to pinpoint a single person behind the growth and development of an academic institution. With many people involved, the individual contribution can easily become blurred with elapsing time. There are however glorious instances, where a single person, owing to inherent qualities, lays a solid foundation for initial development of an institution and prepares it for future challenges. There is no doubt that in the case of the Department of Zoology of the Jagiellonian University Professor Stanislaw Smreczynski was such a person. Here, I will present his biography and achievements and a brief history of the Department.

The scientific interest in zoology at the Jagiellonian University has a long and complex history. Here, we start with the establishment of the first independent zoological unit, the Zoology and Comparative Anatomy Chair within the Faculty of Philosophy in 1850. This unit survived for 40 years when it was split into two Chairs: Zoology and Comparative Anatomy. The latter was led first by Kazimierz Kostanecki and then Henryk Hoyer, the founding fathers of Krakow's school of anatomy. The history and significance of this school is presented elsewhere in this volume (see Kilarski in this volume). Since its foundation, the Zoology Chair, initially led by Antoni Wierzejski, frequently changed its name and scope reflecting changes in the administrative policy and its own development. After the World War II, in 1946, Stanislaw Smreczynski became a head of the Zoology Chair (his predecessor, professor Michal Siedlecki, died in 1940 in the concentration camp in Sachsenhausen). In the early 1960s, there were two departments within the Chair: Systematic Zoology and Invertebrate Embryology. In 1973 these departments fused into the Department of Systematic Zoology and Zoogeography, further referred to as the Department of Zoology, which exists to date as a part of the Institute of Zoology within the Faculty of Biology and Earth Sciences.

Stanislaw Smreczynski was born in 1899 in Regulice, but spent most of his life in Krakow (Fig. 1). His father, a director of a high school in Krakow, and a passionate amateur entomologist, managed to convey his keen interest in the Polish fauna to his son. In 1917, despite his zoological interest, Smreczynski junior started his higher education by studying law at the Jagiellonian University. Soon however, he realized that the zoology was his true vocation. During the final year of zoological studies he was appointed an assistant to Professor Emil Godlewski, the head of the Department of Biology and Embryology of the Medical Faculty of the Jagiellonian University. Since then his entire professional life was closely linked with the University. He received his doctorate degree in 1924, became an associate professor in 1946 and

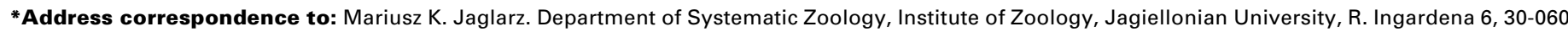
Krakow, Poland. Tel. +48-12-663-2640. Fax: +48-12-634-3716. e-mail: jagla@zuk.iz.uj.edu.pl
}

Published online: 14 February 2008 


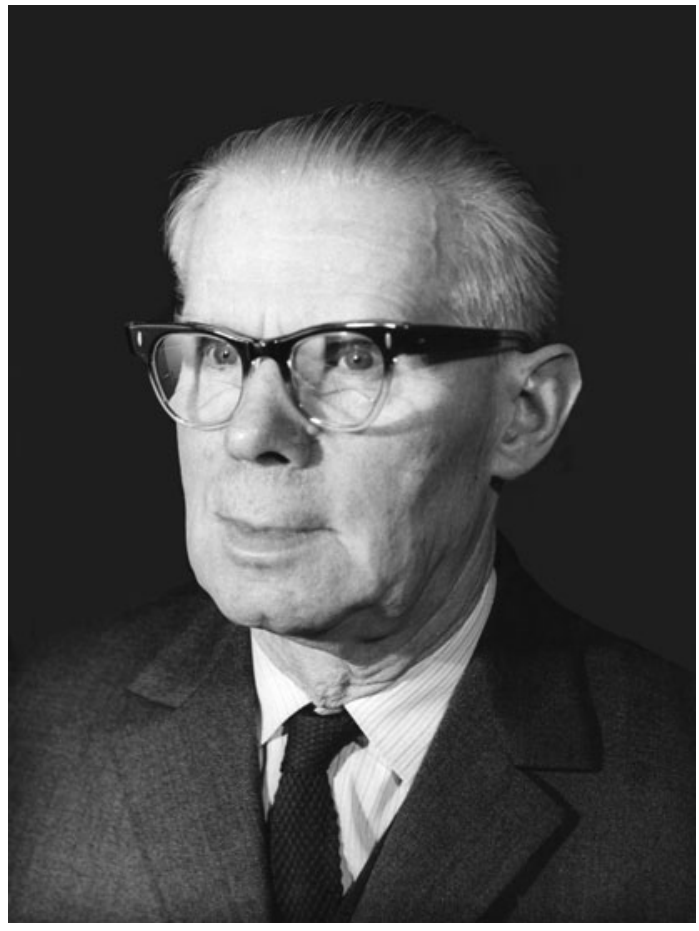

Fig. 1. Professor Stanislaw Smreczynski (1899-1975).

was promoted full professor in 1956. After the doctorate, he expanded his zoological training first in Lwow working with L. Hirshler, and then in Berlin and Paris, where he collaborated with R. Heymons and C. Pérez, respectively.

When Smreczynski began a 23-year career as a head of the Department, it constituted of 6 more scientists and 4 technicians. They had at their disposal a lecture room, a demonstration room, a small library and several rooms cluttered with old furniture, an extensive collection of microscope samples, jars filled with formalin-fixed specimens and pieces of mostly obsolete scientific equipment (Fig. 2). A shining star of the equipment was a Reichert light microscope with phase contrast, a gift of the Rockefeller Foundation.

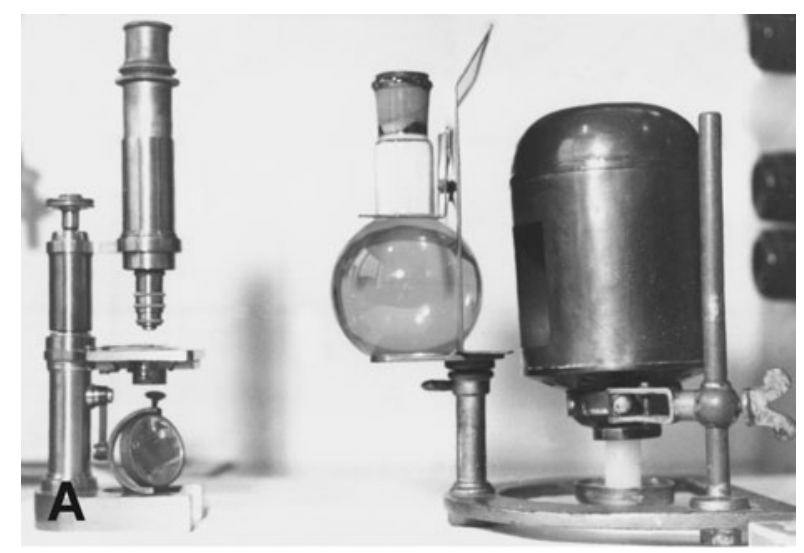

Fig. 2. (A) A light microscope used by Professor Michal Siedlecki at the turn of the 19th and 20th centuries. (B) One of the laboratories where embryology and zoology classes were taught (early 1960s).
The early post-war years were highly unfavorable for the development of science in Poland due to enormous devastation of the country and a dramatic loss of the professional academic staff. Later, during the first decades under the communistic rule in Poland, travel and communication with the West were severely restricted, so scientists coped not only with a profound lack of funds for the advancement of science but more importantly almost non existing access to current scientific ideas and literature, which gradually led to severe isolation. In such non-enticing scientific environment Smreczynski did his research with tremendous passion and enthusiasm and was a constant source of stimulation and encouragement for his colleagues.

In 1951 Smreczynski was elected a dean of the Faculty of Mathematics and Nature and was instrumental in creating an independent unit, the Faculty of Biology and Earth Sciences. In 1963, when the Institute of Zoology was founded, Smreczynski became its first director and remained in office till 1968. He retired in 1969 but continued to work on weevil taxonomy until his death on April 6th 1975. It is worth adding here that Smreczynski was a long time editor of the Acta Biologica Cracoviensia, series Zoology and an assistant editor of the Folia Biologica. He was a member of the Polish Academy of Arts and Sciences and fellow of the Polish Entomological Society, the Polish Zoological Society, the International Union of Biological Sciences - section Entomology, and the Société Entomologique de France.

There are two clearly separated periods in Smreczynski's scientific activity. Before the World War II he spent most of his time studying early stages of amphibian and insect embryonic development. It is amazing how broad was the scope of his research interest and the ease he switched between various developmental systems to explore their particular value in explaining specific

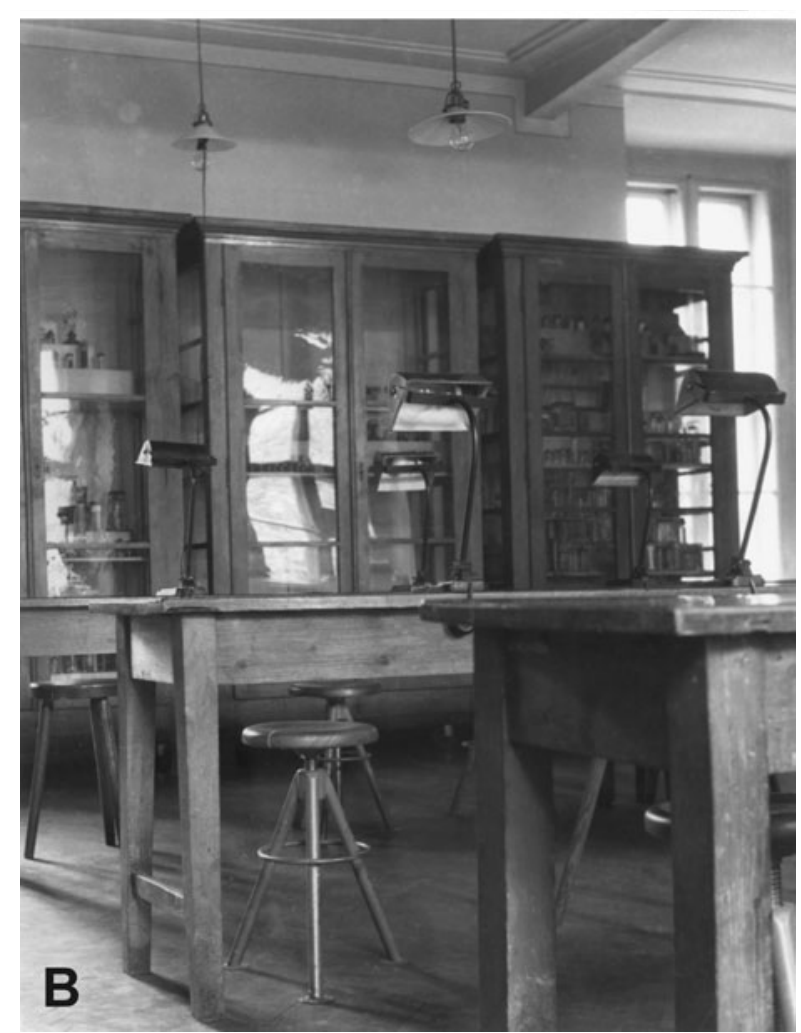


developmental phenomena. Inspired by Spemann's experiments on newts and salamanders, and encouraged by his mentor Godlewski, Smreczynski embarked with great enthusiasm on several projects concerning various aspects of amphibian development. One of these projects addressed a much debated and at the time controversial issue of the localization of the cytoplasmic material from which the neural plate develops in the frog embryos. He conducted numerous experiments in which he inflicted slight physical damage to various regions of the early cleaving embryos using fine glass needles. These experiments led him to conclusion that in frogs the material from which the neural plate develops resides within the cytoplasm of the animal hemisphere of the egg (Smreczynski, 1927). He also studied the sensitivity of the eggs and early embryos to mechanical injury and found that there was an anterior-posterior gradient of the ability to compensate for the damage. At that time, the glass needles, hair loops and binocular microscopes were the primary research tools of embryologists, and the analysis could not proceed beyond the cellular level. Later, inspired by the Spemann's research, Smreczynski analyzed regulatory mechanisms during frog development as well as the significance of the dorsal lip region for the gastrulation process (Smreczynski, 1929).

Professor Smreczynski found also the insect world endlessly fascinating and devoted several years of his life investigating the development of these creatures. In particular, he studied the formation of body segments during embryogenesis and became actively involved in the heated debate over the number of segments in the insect head. Because a continuous layer of cuticle covers the insect head, it is impossible to tell from its external morphology alone how many segments it contains. At the beginning of XX century entomologists profoundly disagreed over the exact number of segments in insect head and different groups opted for 5, 6 or even 7 segments. Smreczynski's reports (1931, 1932) on the embryonic development of the head in a burying beetle, Silpha obscura contributed to the currently held view that there are six segments. The controversy over the head segments was not, as it may seem, an artificially created academic problem, but one with far-reaching implications for the evolution of different arthropod groups and their phylogenetic links. These issues ignite a considerable interest of scientists to the present day. The evidence coming from earlier, purely descriptive morphological research is now extended and corroborated by the studies of genes responsible for the patterning of the body, including Hox genes, which specify the identity of insect segments (Averof and Akam, 1995). Other Smreczynski's valuable contributions to insect embryology are: a detailed description of the embryonic envelope formation in the weevil Phyllobius glaucus (Smreczynski, 1934) and a comprehensive account of the embryonic development of the beetle Agelastica alni (Smreczynski, 1938). These studies made lasting contributions to entomology textbooks. Smreczynski's work in insect embryology has been a powerful stimulus to others and his ideas will continue to influence and illuminate many aspects of the field.

Smreczynski's adventure with embryology came to an abrupt end with the outbreak of the World War II. After the war, with his deteriorating sight and increasing burden of administrative duties, Smreczynski devoted himself entirely to taxonomy of Coleoptera, in particular weevils (Curculionidae) and became a world-famous expert on both Pleistocene and extant curculionids. Throughout

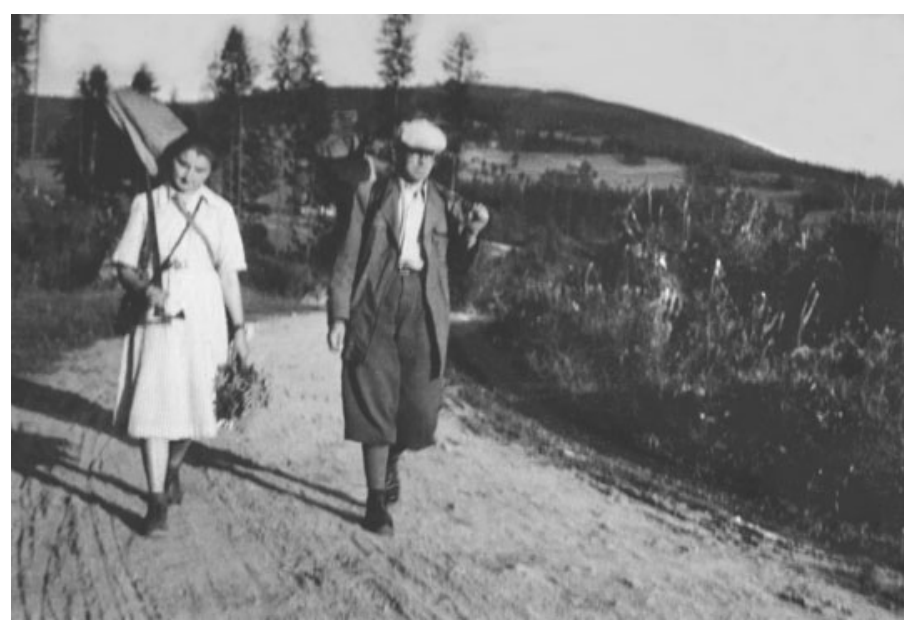

Fig. 3. Professor Smreczynski with his assistant, the late Anna Krzysztofowicz during entomological research in Hucisko (southern Poland), around 1947.

the years he created an extensive collection of beetles, now housed at the Department of Systematic Zoology and Zoogeography. His vital contribution to coleopteran taxonomy has been recognized in several eponyms, e.g. Smicronyx smreczynskii, Solari 1952; Rhynchaenus smreczynskii, Dieckmann 1958; Otiorhynchus smreczynskii, Cmoluch 1968; Apion smreczynskii, Bajtenov 1979.

Professor Smreczynski was renowned for his immense erudition and considered a thinker of great originality. His exceptionally good memory made him a reliable source of various nature facts. He was not only comprehensively educated zoologists but also a man of considerable personal charm so he easily attracted people to work with him. As a leader, he created a friendly atmosphere and skillfully stimulated interest in scientific problems in his students. He always showed considerable tact and patience with students, but at the same time he was a demanding examiner and zoology exams ranked high on the student list of difficulty. Some of his detailed exam questions concerning insect anatomy became legendary.

Smreczynski was able to convey his enthusiasm for embryological experiments and passion for investigating insects as well as other animals to a group of his students, among them Zofia Bielanska-Osuchowska, Anna Czapik, Czeslaw Jura, Zbigniew Kawecki, Anna Krzysztofowicz, Wiktor Micherdzinski, Boguslaw Petryszak, Barbara Weglarska and others (Fig. 3). Due to space limitation, selected research results of only a few Smreczynski's students are briefly presented.

In 1960s researchers in the Department were predominantly concentrated on the precise description of morphological changes during insect embryonic development. More modern experimental and histochemical approach became possible with acquiring technically more advanced pieces of equipment like Zeiss light microscopes, ultramicrotomes and Tesla transmission electron microscopes. Thanks to scholarships the communication with foreign academic centers became more vivid enabling exchange of ideas and contacts with up-to-date scientific information and equipment.

Inspired by Smreczynski, his former students Jura and Krzysztofowicz became interested in various aspects of develop- 
mental biology of Entognatha, a group of relatively small, wingless and otherwise inconspicuous arthropods, considered to be a sister group to true insects (Insecta $s$. str.) (Hennig, 1981; Kristensen, 1981). Entognatha, comprising Protura, Collembola and Diplura, remain poorly studied yet they are extremely interesting for developmental biologists and zoologists alike. They are the most primitive group within Hexapoda and may provide valuable clues about the evolution of certain features within the entire arthropod group. For instance, in most insects, egg undergoes an unusual type of development called syncytial (superficial) cleavage, which initially encompasses only nuclear divisions. The formation of membranes separating the superficially located nuclei, i.e. cytokinesis, occurs much later in development. It is not entirely clear how this type of cleavage evolved and in this respect the entognathans are of particular interest because this arthropod group contains a wide spectrum of transitions from total to truly superficial cleavage.

The studies initiated by Jura and continued together with
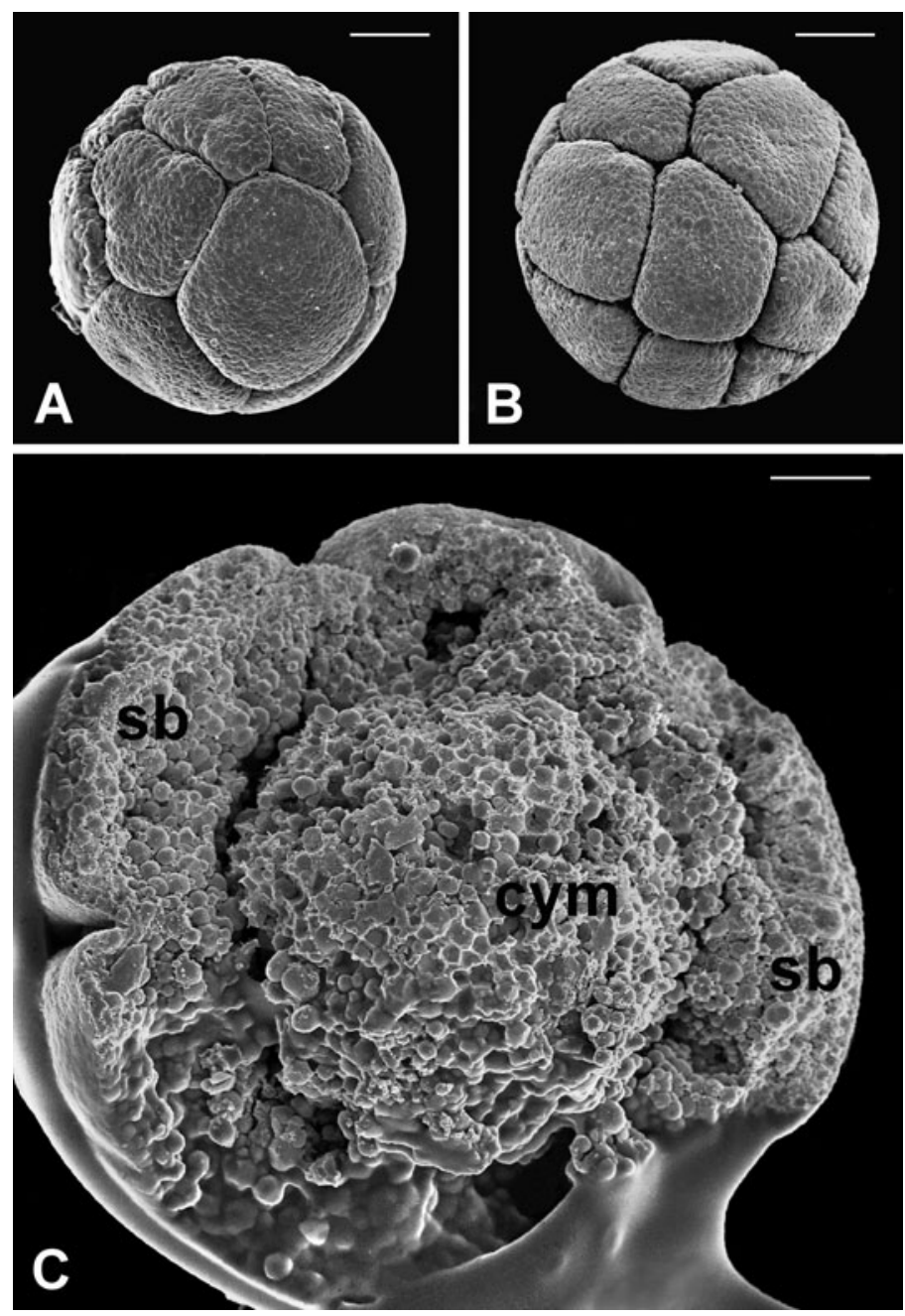

Fig. 4. Scanning electron micrographs of the early embryo of Tetrodontophora bielanensis (taken by Jura and Krzysztofowicz). (A) An embryo at the transition from 8- to 16-blastomere stage. (B) 16blastomere stage. (C) A cutaway view of the 16-blastomere embryo showing a central yolk mass (cym) separated from the superficial blastomeres (sb). Scale bars (A,B) $100 \mu \mathrm{m},(C) 50 \mu \mathrm{m}$.
Krzysztofowicz and collaborators focused on development of a representative of Collembola, Tetrodontophora bielanensis. This springtail lays spherical eggs, covered by a vitelline envelope and chorion. The eggs are rich in yolk, centrolecithal but in contrast to the eggs of most insects, do not contain the yolk-free periplasm. During fertilization 2-4 sperms enter the oocyte (Jura and Krzysztofowicz, 1992). Surprisingly, as Jura demonstrated in sectioned material, the early cleavage of feritilized eggs is initially total, i.e. nuclear divisions are followed by cytokinesis, and continues until the embryo reaches the eight-blstomere stage (Fig. 4A) (Jura, 1965). Subsequently, a superficial cleavage is initiated and a rather complex sequence of divisions forms a periblastula (Fig. 4B, C) (reviewed in Jura, 1972). Jura addressed also a puzzling problem of gastrulation in collembolan embryos as well as the differentiation of the blastoderm into the germ band, dorsal organ and embryonic membranes (Jura 1965, 1967b). He also investigated the midgut formation and the origin of endoderm, probably the most controversial and disputed issues in entognathan embryology. He proposed, that the midgut primordium forms during embryonic development from the blastomeres, which initially contribute to yolk and turn into vitellophages (Jura, 1966).

Careful and methodical studies of entognathan reproduction and development focused at some point on the structure of the ovary in Protura and especially Collembola, almost completely unknown at the time. Investigating the processes of germ cluster formation, yolk accumulation and egg envelope deposition Jura and collaborators found some similarities with Insecta $s$. str., but more importantly, some essential differences as well. The ovaries of Collembola and Protura are sac shaped and not divided into a discrete ovarioles as in majority of insects (Jura, 1975; Krzysztofowicz, 1977). The ovaries in Protura are of the peculiar, neopanoistic type, while those in Collembola are polytrophicmeroistic (reviewed in Bilinski, 1994). Later works by Bilinski and Klag showed, contrary to a traditional view, that the entognathan oocytes are indeed covered by somatic cells resembling a simple follicular epithelium (Bilinski, 1977, 1979; Klag, 1978). Moreover, there are gap junctions present between the oocyte and the surrounding somatic cells and, as in other insect systems, they are likely to coordinate differentiation of the connected cells (Bilinski and Klag, 1982). Although the formation of germ cell clusters in collembolan ovaries has not been entirely elucidated, it was demonstrated that the germline clones are not branched as in most meroistic insect ovaries but linear (reviewed in Bilinski, 1994). It was also found that in Collembola and some Diplura the oocyte differentiates from a gonial cell located more or less centrally within the linear germline clone (Bilinski, 1983).

Krzysztofowicz introduced autoradiographic and histochemical techniques into the studies of oogenesis in Collembola. She showed that besides the 'canonical' nurse cells actively involved in RNA synthesis, the oocyte is flanked on either side by intermediate cells, originally termed blocking cells, which are transcriptionally dormant and appear to participate only in the transport of macromolecules and organelles from the proper nurse cells into the oocyte (Krzysztofowicz, 1971, 1975).

Another area of Jura's research interest revolved around germ cell determination and gonad formation. Jura noticed that in $T$. bielanesis the germ cells originate in the 64-cell stage embryo from two to five superficial blastomeres, the first that divide 


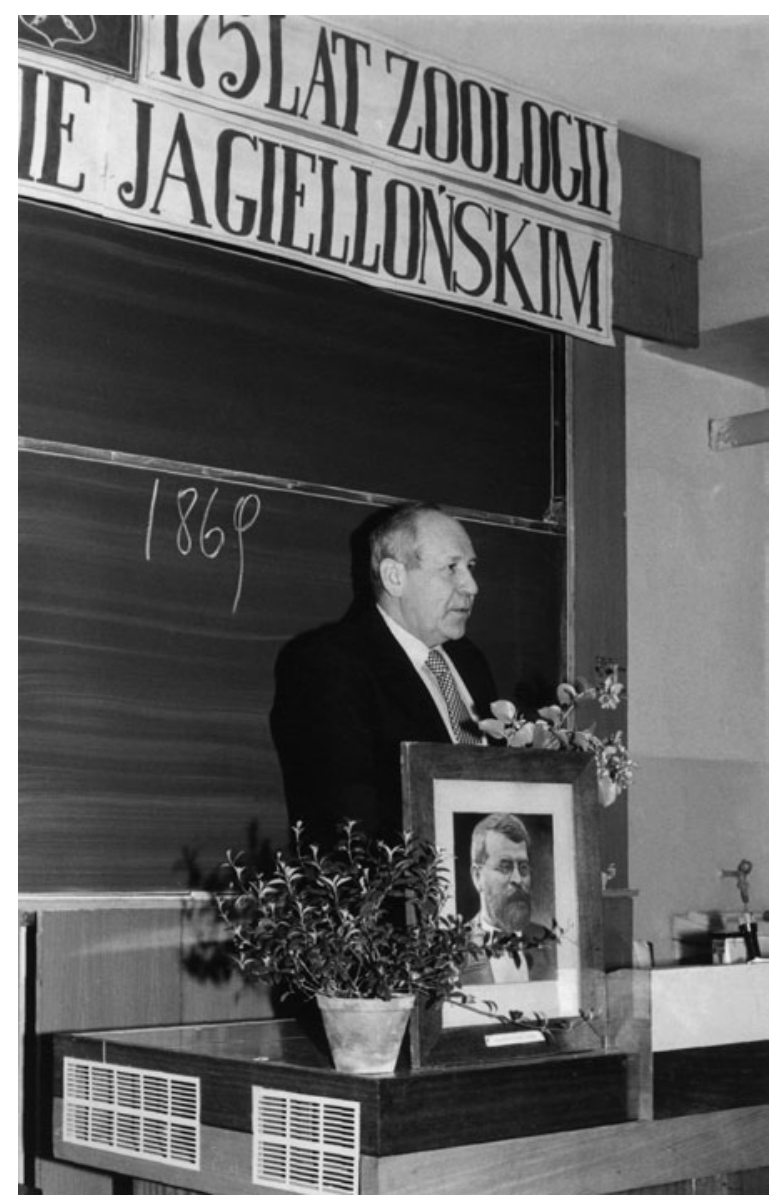

Fig. 5. Professor Czeslaw Jura, Dean of the Faculty of Biology and Earth Sciences, giving the opening lecture at the inauguration of the 175th Anniversary of zoology at the Jagiellonian University, March 1988. The portrait on the desk is of Maksymilian Sila-Nowicki, the first Polish zoologist appointed to the Zoology and Comparative Anatomy Chair at the Jagiellonian University.

tangentially (Jura, 1967a). Using classical histochemical techniques he was however unable to detect any germ cell determinants in collembolan eggs. It would be very interesting to reinvestigate this problem using modern molecular markers. Jura's cytological and experimental studies on the pole cells formation and their developmental fate in Drosophila virilis showed that the destruction of the posterior pole plasm or pole cells by UV irradiation results in the absence of primordial germ cells but does not disturb the development of the somatic part of the gonad (Jura, 1964a, b). These findings have been fully corroborated by genetic and molecular studies of the model fruit fly Drosophila melanogaster (reviewed in Nieuwkoop and Sutasurya, 1981; Saffman and Lasko, 1999).

Other Smreczynski's students became interested in comparative anatomy, spermatogenesis, oogenesis, parthenogenesis and postembryonic development in a wide spectrum of insect groups including bristletails, dragonflies, stoneflies, homopteran and heteropteran bugs, and beetles. They explored also embryogenesis of molluscs and amphibians. Barbara Weglarska for instance investigated embryonic development of weevils and internal anatomy of coccids, but later switched to an entirely different invertebrate group, the tardigrades (Tardigrada). She provided first ultrastructural data on the previtellogenic and vitellogenic growth of the oocytes in Eutardigrada and made important contribution to our understanding of their excretory system (Weglarska, $1979 ; 1980)$. She also studied the process of anabiosis in tardigrades.

After Smreczynski's retirement, his student and collaborator, Czeslaw Jura became the head of the Department (Fig. 5). Under his leadership, lasting over 20 years, the Department continued two main research interests initiated by Smreczynski: developmental biology of invertebrates, primarily hexapods (as presented above), and insect taxonomy. Jura's collaboration with Professor Hiroshi Ando (University of Tsukuba, Japan) resulted in publication of a book 'Recent Advances in Insect Embryology in Japan and Poland (1987) with many contributions by researchers from the Department. After Jura's retirement in 1997, the head of the Department became Szczepan Bilinski. In 1999 the Department was split into two units along the research interest. Within the developmental biology unit, several independent researchers continued studies of various aspects of invertebrate development. In particular, a group led by Bilinski concentrated on the structure of the ovary and germ cell cluster formation in different insect groups and its relevance to phylogenetic inference. This research resulted in a series of papers reviewed in the Biological Reviewsin 1990 and in a special edition of the Folia Histochemica et Cytobiologica in 1998 (Stys and Bilinski, 1990; Bilinski, 1998; Bilinski et al., 1998; Jaglarz, 1998; Kubrakiewicz et al., 1998 a,b; Szklarzewicz, 1998). Most recently, Bilinski has directed the group's research effort towards studies of follicular epithelium differentiation in insects and, in collaboration with Malgorzata Kloc (The University of Texas, USA), oogenesis and early embryonic development of Xenopus. Bilinski's outstanding research achievements and significant contributions to many aspects of both insect and Xenopus oogenesis merit a separate analysis. In 2005 Bilinski was elected a vice-Rector of the Jagiellonian University and increasingly more demanding administrative duties forced him to hand down the leadership of the Department to the assistant professor Teresa Szklarzewicz.

Smreczynski's legacy continues to influence a new generation of developmental biologists in the Department of Zoology. They embark on projects aimed at linking morphological and molecular features of insect and amphibian oogenesis with their significance for early embryonic development [e.g. see in this issue Jaglarz et al. (2008); Pyka-Fosciak et al. (2008)].

\section{Acknowledgement}

I am deeply grateful to Professor Czeslaw Jura for generously sharing with me his extensive knowledge on various facts related to the Department history and for providing the photographs. I thank Professors Czeslaw Jura and Szczepan Bilinski for critical reading of the manuscript.

\section{References}

AVEROF, M. and AKAM, M. (1995). Hox genes and the diversification of insect and crustacean body plans. Nature 376: 420-423.

BILINSKI, S. (1977). Oogenesis in Acerentomon gallicum Jonescu (Protura). Cell Tissue Res. 179: 401-412.

BILINSKI, S. (1979). Oogenesis in Campodea sp. (Diplura). The ultrastruture of the egg chamber during vitellogenesis. Cell Tissue Res. 202: 133-143.

BILINSKI, S. (1983). Differentiation of the oocyte and nurse cells in an apterygote 


\section{M.K. Jaglarz}

insect (Campodea). Tissue Cel/15: 965-973.

BILINSKI, S. (1994). The ovary of Entognatha. In The insect ovary. UItrastructure, previtellogenic growth and evolution. (ed. Buning, J.) Chapman and Hall, London, pp. 7-30.

BILINSKI, S.M. (1998). Ovaries, oogenesis and insect phylogeny. Introductory remarks. Folia Histochem. Cytobiol. 36: 143-145.

BILINSKI, S.M., BUNING, J. and SIMICZYJEW, B. (1998). The ovaries of Mecoptera: basic similarities and one exception to the rule. Folia Histochem. Cytobiol. 36: 189-195.

BILINSKI, S. and KLAG, J. (1982). Gap junctions between oocyte and follicle cells in Acerentomon sp. (Insecta, Protura). Int. J. Invert. Reprod. 5: 331-335.

HENNING, W. (1981). Insect Phylogeny. Wiley and Sons, New York.

JAGLARZ, M.K. (1998). The number that counts. Phylogenetic implications of the number of nurse cells in ovarian follicles of Coleoptera-Adephaga. Folia Histochem. Cytobiol. 36: 167-178.

JAGLARZ, M.K., KLOC, M. and BILINSKI, S.M. (2008). Accessory nuclei in insect oogenesis: in search of the function of enigmatic organelles. Int. J. Dev. Biol. 52: 179-185.

JURA, C. (1964a). Cytological and experimental observations on the origin and fate of the pole cells in Drosophila virilis Sturt. Part I. Cytological analysis. Acta Biol. Cracov., ser. Zool. 7: 59-73.

JURA, C. (1964b). Cytological and experimental observations on the origin and fate of the pole cells in Drosophila virilis Sturt. Part II. Experimental analysis. Acta Biol. Cracov., ser. Zool. 7: 89-103.

JURA, C. (1965). Embryonic development of Tetrodontophora bielanensis (Waga) (Colembola) from oviposition till germ band formation stage. Acta Biol. Cracov., ser. Zool. 8: 141-157.

JURA, C. (1966). Origin of the endoderm and embryogenesis of the alimentary system in Tetrodontophorabielanensis (Waga) (Colembola). ActaBiol. Cracov., ser. Zool. 9: 93-102.

JURA, C. (1967a). Origin of germ cells and gonads formation in embryogenesis of Tetrodontophora bielanensis (Waga) (Colembola). Acta Biol. Cracov., ser. Zool. 10: 97-103.

JURA, C. (1967b). The significance and function of the primary dorsal organ in embryonic development of Tetrodontophora bielanensis (Waga) (Colembola). Acta Biol. Cracov., ser. Zool. 10: 301-310.

JURA, C. (1972). Development of apterygote insects. In Developmental Systems. Insects, vol. 1 (eds. Counce, S.J. and Waddington, C.H.) Academic Press, London and New York. pp. 49-94.

JURA, C. (1975). Ovaries structure in Acerentomon dispar Stach (Protura). Acta Biol. Cracov., ser. Zool. 18: 55-65.

JURA, C. and KRZYSZTOFOWICZ, A. (1992). Initiation of embryonic development in Tetrodontophorabielanensis(Waga) (Colembola) eggs: meiosis, polyspermy, union of gametes and the first cleavage. Int. J. Insect. Morphol. Embryol. 21: 8794.

KLAG, J. (1978). Oogenesis in Acerentomon gallicum Jonescu (Protura). An ultrastructural analysis of the early previtellogenic stages. Cel/ Tissue Res. 189: 365-374.

KRISTENSEN, N.P. (1981). Phylogeny of insect orders. Ann. Rev. Entomol. 26: 135-157.
KRZYSZTOFOWICZ, A. (1971). Histochemical and autoradiographic analysis of RNA synthesis in the trophic cells of the female gonad in Tetrodontophora bielanensis (Waga) (Colembola). Acta Biol. Cracov., ser. Zool. 14: 299-305.

KRZYSZTOFOWICZ, A. (1975). Histochemical and ultrastructural analysis of blocking nurse cells in the female gonad of Tetrodontophorabielanensis (Waga) (Colembola). Acta Biol. Cracov., ser. Zool. 18: 45-53.

KRZYSZTOFOWICZ, A. (1977). Les etudes comparatives sur la morphologie des ovaires chez les Collemboles. Rev. Ecol. Biol. Sol. 14: 81-90.

KUBRAKIEWICZ, J., BILINSKI, S.M. and MAZURKIEWICZ, M. (1998a). Diptera ovary structure and oogenesis in midges and flies. Folia Histochem. Cytobiol. 36: 197-203.

KUBRAKIEWICZ, J., JEDRZEJOWSKA, I., and BILINSKI, S.M. (1998b). Neuropteroidea - different ovary structure in related groups. Folia Histochem. Cytobiol. 36: 179-187.

NIEUWKOOP, P.D. and SUTASURYA, L.A. (1981). Primordial Germ Cells in the Invertebrates: from epigenesis to preformation. Cambridge, Cambridge University Press.

PYKA-FOSCIAK, G. and SZKLARZEWICZ, T. (2008). Germ cell cluster formation and ovariole structure in viviparous and oviparous generations of the aphid Stomaphis quercus. Int. J. Dev. Biol. 52: 259-265.

SAFFMAN, E.E. and LASKO, P. (1999). Germline development in vertebrates and invertebrates. Cell. Mol. Life Sci. 55:1141-1163.

SMRECZYNSKI, S. (1927). Les résultats des recherches sur la localisation de l'embryon virtuel dans l'oeuf de grenouille, obtenus en enfonçant des aiguilles de verre. Bull. Acad. Pol. Sci. Lett., Cl. Sci. Math. Nat. Sér. B. 739-749.

SMRECZYNSKI, S. (1929). Experimentelle Untersuchungen uber die Empfindlichkeit gegen mechanische Reize und uber den Verlauf der anormalen Gastrulation im Ei von Rana fusca. Bull. Acad. Pol. Sci. Lett., Cl. Sci. Math. Nat. Sér. B. 67-100.

SMRECZYNSKI, S. (1931). Embryologische Untersuchungen uber die Entwicklung des Kopfes von Silpha obscura L. (Coleoptera). Bull. Acad. Pol. Sci. Lett., Cl. Sci. Math. Nat. Sér. B. 649-651.

SMRECZYNSKI, S. (1932). Embryologische Untersuchungen uber die Zusammensetzung des Kopfes von Silpha obscura L. (Coleoptera). Zool. Jb. Abt. Anat. Ont. 55: 137-314.

SMRECZYNSKI, S. (1934). Beitrag zur Kenntnis der Entwicklungsgeschichte des Russelkäfers Phyllobius glaucus Scop. (Coleoptera). Bull. Acad. Pol. Sci. Lett., Cl. Sci. Math. Nat. Sér. B. 287-312.

SMRECZYNSKI, S. (1938). Entwicklungsmechanische Untersuchungen am Ei des Käfers Agelastica alni L. Zool. Jb. Abt. Zool. Physiol. 59: 1-58.

STYS, P. and BILINSKI, S. (1990). Ovariole types and the phylogeny of hexapods. Biol. Rev. 65: 401-429.

SZKLARZEWICZ, T. (1998). The ovaries of scale insects (Hemiptera, Coccinea). Morphology and phylogenetic conclusions. Folia Histochem. Cytobiol. 36: 157165.

WEGLARSKA, B. (1979). Electron microscope study of previtellogenesis and vitellogenesis in Macrobiotus richtersi J Murr (Eutardigrada). Zesz. Nauk. UJ Zool. 25: 169-189.

WEGLARSKA, B. (1980). Light and electron microscopic studies on the excretory system of Macrobiotus richtersiMurray, 1911 (Eutardigrada). Cell Tissue Res. 207: 171-182. 


\section{Related, previously published Int. J. Dev. Biol. articles}

See our recent Special Issue Developmental Biology in Poland edited by Kloc, Maleszewski and Tarkowski at: http://www.ijdb.ehu.es/web/contents.php?vol=52\&issue=2-3

See our Special Issue Mammalian Reproduction \& Development in honor of Anne McLaren and edited by Brigid Hogan at: http://www.ijdb.ehu.es/web/contents. php?vol=45\&issue $=3$

Sclerotome development and morphogenesis: when experimental embryology meets genetics

Anne-Hélène Monsoro-Burq

Int. J. Dev. Biol. (2005) 49: 301-308

Mammalian neural tube grafting experiments: an in vitro system for mouse experimental embryology.

D Echevarría, C Vieira and S Martínez

Int. J. Dev. Biol. (2001) 45: 895-902

Experimental embryology in Soviet Russia: the case of Dmitrii P. Filatov (1876-1943).

T A Dettlaff and S G Vassetzky

Int. J. Dev. Biol. (1997) 41: 781-787

Experimental embryology in Japan, 1930-1960. A historical background of developmental biology in Japan.

T S Okada

Int. J. Dev. Biol. (1994) 38: 135-154

A pioneer of experimental mammalian embryology: Jacques Mulnard.

$\mathrm{H}$ Alexandre

Int. J. Dev. Biol. (1992) 36: 25-27

Experimental embryology in France (1887-1936).

$\mathrm{J} L$ Fischer

Int. J. Dev. Biol. (1990) 34: 11-23

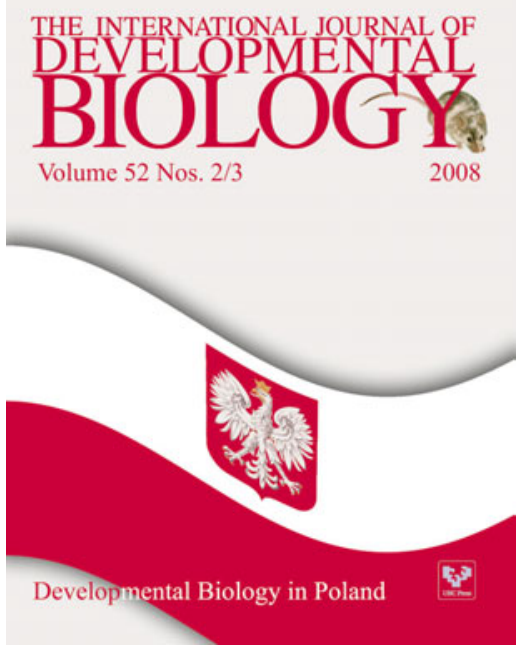

2006 ISI **Impact Factor $=3.577^{\star *}$

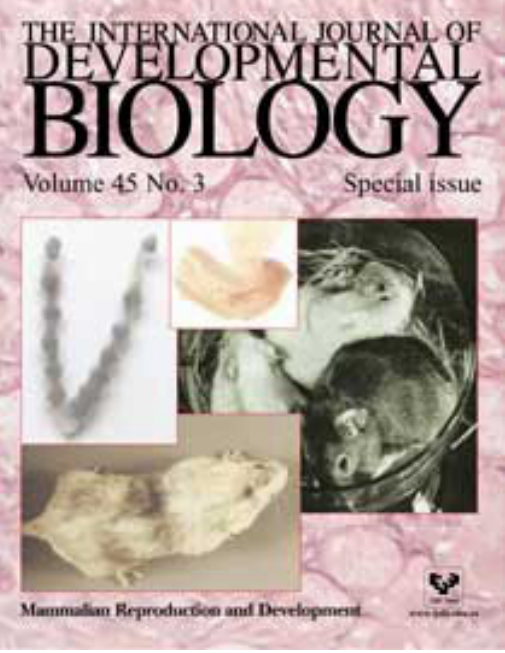

